\title{
Anti HIV Prolific Drug Discovery
}

\author{
Dr.Mukesh H.Shukla ${ }^{\star, \dagger}$ \\ Scientist Ayushi Biotech Immunity Research Centre \\ QDOI: https://doi.org/10.15520/jcmro.v2i11.230
}

Accepted 31-10-2019; Received 20-10-2019; Publish Online 01-11-2019

\author{
Reviewed By: \\ Dr. Kratika Daniel \\ Department: \\ Reviewer CMRO
}

\begin{abstract}
HIV is the abbreviations used for the Human Immunodeficiency Virus. HIV attacks the body's immune system. Normally, the immune system produces white blood cells and antibodies that attack viruses and bacteria. The infection fighting cells are called T-cell lymphocytes. Months to years after a person is infected with HIV, the virus destroys all the T-cell lymphocytes. This disables the immune system to defend the body against diseases and tumors. Various infections will be able to develop; these opportunistic infections take advantage of the body's weakened immune system. These infection which normally won't cause severe or fatal health problems will eventually cause the death of the HIV patient
\end{abstract}

\section{BACKGROUND OF THE INVENTION:}

The subject of invention relates to a therapeutic bioactive composition which is likely to be potentially beneficial for immune enhancement, prophylaxis and treatment of HIV / AIDS, Cancers and TB.

1. Acquired immune deficiency syndrome, commonly known as AIDS, is a disease caused by a retrovirus called human immunodeficiency virus (HIV). First recognized in 1981, this devastating disease has spread on an international scale with millions of people worldwide considered to be HIV-infected. The virus preferentially targets the helper $\mathrm{T}$ cells, which play a central role in the functioning of the immune system. In most cases the virus, once incorporated into the helper $\mathrm{T}$ cell, remains dormant for an unspecified tenure. Once activated, however, the virus rapidly destroys the helper T cells, thereby crippling the immune system. It is at this stage that the symptoms of AIDS become evident. These include: enlarged lymphoid glands; unexplained rapid weight loss and diarrhea; fever and night sweats; dermatitis and skin eruptions and lesions; diminished sensitivity to skin tests; memory disorder and behavioral changes; increased incidence of certain cancers (a common tumor of AIDS patients is Kaposi's sarcoma, resulting in purplish marks on the skin); and increased susceptibility to opportunistic infections that rarely infect normal individuals. Currently, there is no cure for AIDS and attempts to produce a vaccine have

* Corresponding author.

$\dagger$ Email: dr.mhshukla@gmail.com been hindered by the fact that the virus is capable of changing its outer membrane configuration.

2. The principal function of the immune system is to protect against infection, by destroying and eliminating invading organisms and any toxic molecules they produce.

3. There may a number of therapeutic compounds observed for the variety of ailments. We have carefully selected some bioactive compounds from the plants of origin and undertaken "Pilot" case study to evaluate the true outcome. Before embarking towards "pilot" case study, we have confirmed the HIV-1 patients with the absolute CD4 Ratio as well as Western Blot test. Within the three to four months' of medication, we observed and found that the bioactive formulation has explicit safety and efficacy in pilot clinical trials on six HIV-1 and HIV-2 human subjects. We had also recommended some explicit plant extracts in dry powder form to enhance immunity.

4. The "Pilot" study for any drug discovery is an essential factor and the prime objective would be to embark further to obtain appropriate therapy as the patient's elementary interest must be maintained with safety, efficacy and dosage determination.

5. We have procured willful consent of the patient / patients to embark further for the novel formulations. 
Untreated HIV disease is a chronic progressive process that begins with infection, is often followed by a "primary HIV syndrome," and progresses in adults over a median period of more than 10 years to the late stage: AIDS. From the time of infection, the virus continuously and rapidly replicates, mutates, and as a result diversifies and evolves in response to selective pressure. Immune system damage also begins upon infection. The burden of virus and the bulk of this process occur in lymphoid tissue, and the immune system struggles to hold the process in check. Slowly, but relentlessly, the process destroys essential components of the host immune system. Progression is often accelerated in infants with prenatal HIV infection. Eventually the host becomes increasingly susceptible to and eventually dies as a result of complications of opportunistic infections and malignancies resulting from immune system dysfunction.

Virus entry:

Several independent lines of evidence demonstrated that CD4 serves as a binding receptor for HIV-1, which bind with high affinity to gp120.Gp120 is a viral surface envelope protein. The post binding events required for HIV-1 and cell membrane fusion are not well understood. HIV-1, like most other retroviruses, infects cells in a pH-independent manner that is consistent with direct fusion between viral and cell surface membranes.

\section{OBJECTIVE:}

"Every 14 seconds a person between 15 and 24 is infected with the virus. They now account for half all new cases of the disease, the U.N. Population Fund said in its annual State of the World's Population report." Since 1981, HIV/AIDS has encapsuled many lives and I focused my attention on the subject to gear up drug discovery efforts through bioactive compounds as all most all conventional drugs have been observed for its undue toxic effects.

My studious efforts to bring out the facts about HIV/AIDS and STD's have been coupled with genetic concept, undesired interaction of various glycoprotein of HIV and the clinical onset of this deadly disease. I propelled my research especially on immunity base and at the same time to control viral load, in particular p17 and p24 which are the notorious glycoprotein as seriously considered by the internationally renowned scientific community. Further to assess various bioactive compounds and formulation/s whether its chemical entities, synergistic actions, safety and efficacy have prolific outcome to remove or expunge notorious glycoproteins of HIV-1 and HIV-2 through pilot case study. The human clinical pilot case study has fetched outstanding results; confirmed by the periodical WB tests.

\section{SUMMARY OF GLYCOPROTEINS AND ITS ROLE ON HIV INFECTED INDIVIDUAL:}

HIV-1 replication is a dynamic process influenced by a combination of viral and host factors. The HIV-1 matrix protein p17 is a structural protein critically involved in most stages of the life cycle of the retrovirus. It participates in the early stages of virus replication as well as in RNA targeting to the plasma membrane, incorporation of the envelope into virions and article assembly. Besides its well established functions, p17 acts as a viral cytokine that works on preactivated - but not on resting - human $\mathrm{T}$ cells promoting proliferation, proinflammatory cytokines release and HIV1 replication after binding to a cellular receptor (p17R). Thus, p17 might play a key role in the complex network of host- and virus-derived stimulatory factors contributing to create a favourable environment for HIV-1 infection and replication.

Here, we present a brief overview of the functions played by the matrix protein p17 in the HIV-1 life cycle and summarize the current understanding of how p17 could contribute to the pathogenesis of HIV-1 disease. [1]

HIV-1 p17 increased the cytokines interleukin (IL) 2, IL-12 and IL-15, and induced natural killer cell proliferation, but not cytotoxicity. This effect was specific because it was abrogated by anti-p17 monoclonal antibody. Moreover, HIV-1 p17 enhanced the cytokine-induced production of tumour necrosis factor (TNF)- and interferon (IFN)- by NK cells. IL-4 down regulated IFN- and TNF- secretion in IL-2- and IL-15-treated NK cells. HIV-1 p17 restored the ability of NK cells to produce both cytokines when added to the cultures simultaneously with IL-4. The property of p17 to increase the production of TNF- and IFN- might be a mechanism used by HIV-1 to modulate the immune system to support its replication and spreading [2] .

The human immunodeficiency virus (HIV) matrix protein, p17, forms the outer shell of the core of the virus, lining the inner surface of the viral membrane. The protein has several key functions. It orchestrates viral assembly via targeting signals that direct the gag precursor polyprotein, $\mathrm{p} 55$, to the host cell membrane and it interacts with the transmembrane protein, gp41, to retain the env-encoded proteins in the virus. In addition, p17 contains a nuclear localisation signal that directs the pre-integration complex to the nucleus of infected cells. This permits the virus to infect productively non-dividing cells, a distinguishing feature of HIV and other lentiviruses. We have determined the solution structure of $\mathrm{p} 17$ by nuclear magnetic resonance (NMR) with a root-mean square deviation for the backbone of the well defined regions of $0.9 \AA$. It consists of four helices connected by short loops and an irregular, mixed beta sheet that provides a positively charged surface for interaction with the inner layer of the membrane. The helical topology is unusual; the Brookhaven protein database contains only one similar structure, that of the immune modulator interferon-gamma [3] .

Because of its conservative amino acid sequence and the consistency of anti-p17 level in vivo with the deterioration of clinical status, it is of interest to investigate the role of antip17 in a natural course of HIV infection. In this study, neutralizing activity of human anti-p17 purified from HIV carriers' plasma was determined. MATERIALS AND METHODS: Affinity column chromatography was performed to detect human anti-p17. Recombinant p17 (kindly provided by 
Dr. Shinagawa) and glycine-HCl (pH2.5) buffer were used for a ligand and an elution buffer, respectively. Anti-p17 was challenged to HIV JH3 (20 or 200 TCID50/well) isolated from a Japanese HIV carrier to determine a neutralizing activity. Peripheral blood mononuclear cells from HIV seronegative donors were used for target cells. HIV replication levels in the additional culture were assessed by p24 gag protein production.

\section{RESULTS AND DISCUSSION:}

HIV infectivity was impaired after exposure to each antip17, which was apparently observed when human anti-p17 was challenged to decreased HIV dose (20 TCID50). p24 protein production was significantly suppressed to less than $10 \%$ as compared to control after an exposure to anti-p17. Neutralizing activity of human anti-p17 observed in vitro may imply its actual influence on HIV infection in vivo. This result is encouraging the further careful investigation of anti-p17.

The affinity of anti-gag antibody was studied for up to 9 years (1984-1993) in sera from 15 HIV-1+ patients with haemophilia. On the basis of their 1993 clinical status patients were divided into two groups: (i) patients who remained asymptomatic ( $\mathrm{n}=9$ ); and (ii) those who progressed to AIDS between late 1987 and 1993. The affinity constants of antibody for p24 and p17 were determined by a double isotope fluid-phase radioimmunoassay; and the relationships between antibody affinity and titre, patient clinical course, CD4 cell counts and p24 antigenaemia were analysed. The affinity of p24- and p17-specific antibody was up to 100 times greater in asymptomatic patients than in patients who progressed to AIDS. Patients who developed AIDS either lost or failed to develop high-affinity antibodies early in the infection. Asymptomatic patients maintained high-affinity antibodies for several years; however, in some of these patients the affinity of anti-p24 and p17 antibodies subsequently fell later in the study period. The presence of low-affinity antibody and progressive reduction in the titre of specific antibody were earlier predictors of disease onset than CD4 cell counts. The failure to either develop or maintain high affinity gag-specific antibody suggests an early impairment of $\mathrm{T}$ helper function in individuals who progressed to AIDS. The presence of antibody of high affinity could be essential in controlling virus replication and the onset of AIDS. [4]

Purified recombinant HIV-1 p17 matrix protein significantly increased HIV-1 replication in preactivated peripheral blood mononuclear cell cultures obtained from healthy donors. Because HIV-1 infection and replication is related to cell activation and differentiation status, in the present study, we investigated the role played by p17 during the process of $\mathrm{T}$ cell stimulation. Using freshly isolated peripheral blood mononuclear cells, we demonstrate that p17 was able to enhance levels of tumor necrosis factor and IFNreleased from cells stimulated by IL-2. IL- 4 was found to down-regulate IFN- and tumor necrosis factor, and p17 restored the ability of cells to produce both cytokines. The property of p17 to increase production of proinflammatory cytokines could be a mechanism exploited by the virus to create a more suitable environment for HIV-1 infection and replication. Our data show that p17 exerts its biological activity after binding to a specific cellular receptor expressed on activated $\mathrm{T}$ lymphocytes. The functional p17 epitope involved in receptor binding was found to be located at the NH2-terminal region of viral protein. Immunization of $\mathrm{BALB} / \mathrm{c}$ mice with a 14 -aa synthetic peptide representative of the HIV-1 p17 functional region (SGGELDRWEKIRLR) resulted in the development of p17 neutralizing antibodies capable of blocking the interaction between p17 and its cellular receptor. Our results define a role for p17 in HIV-1 pathogenesis and contribute to our understanding of the molecular mechanism of HIV-1 infection and the development of additional antiviral [5]

Monocytes play a central role in the immune system by producing and reacting to different soluble factors. Cytokine dysregulation is a hallmark in HIV-infected individuals and it is one of the most significant factors leading to impaired immunity in HIV/AIDS disease. This study investigates the possibility of modulation in the secretion of some inflammatory cytokines and chemokines induced by HIV p17 in monocytes. The results show that p17, while ineffective on resting monocytes, exerts an inflammatory action on IL-4 mediated inhibition of TNF- $\alpha$ and IFN- $\gamma$ production induced by IL-15 stimulation. In addition, p17 is able to reduce MIP- $1 \alpha$ secretion, but unable to influence IL-6 production. The ability of HIV p17 to contribute to an altered pattern of secreted soluble factors might imply a key role for this viral protein in the development of AIDS pathogenesis. [6]

\section{p24 (HIV):}

A major core protein of the human immunodeficiency virus encoded by the HIV gag gene. HIV-seropositive individuals mount a significant immune response to p24 and thus detection of antibodies to p24 is one basis for determining HIV infection by ELISA and Western blot assays. The protein is also being investigated as a potential HIV immunogen in vaccines.

Recombinant transposing vector pFHIV24 was constructed by cloning the HIV-1 p24 gene into the multiple cloning sites (MCS) of the transposing vector pFastBac1 in the correct orientation with respect to the polyhedrin promoter. Recombinant bacmid bHIV24 was obtained by transposing a mini-att $\operatorname{Tn} 7$ element from the recombinant pFHIV24 to the mini-att Tn7 attachment site on the bacmid by $\operatorname{Tn} 7$ transposition functions provided by the helper plasmid. Minipreparation of recombinant bacmid DNA was transfected into Spodoptera frugiperda (Sf9) cells to get the recombinant virus. Fresh insect Sf9 cells were infected with the recombinant virus containing p24 to express the target protein. The target protein expressed was analyzed on $15 \%$ polyacrylamide gels and then used as antigen to check HIV1 positive serum by ELISA. Our positive result shows that the expressed p24 protein could be used as standard antigen for HIV-1 diagnosis by ELISA and other reliable diagnostic methods of HIV-1 infection [7] 
Proteins from the inner core of HIV-1 are involved in crucial processes during the virus life cycle. p24 is the major capsid protein of HIV and is initially expressed as part of the gag polyprotein. The association of gag proteins to the cell inner-membrane surface initiates virus assembly and induces budding from the host cell membrane. Thus, p24 plays an active structural role both as part of the Gag protein and in its mature form. In this sense, we have chosen a region from C-terminal of p24, TLRAEQASQEVKNWMTETLLVQNA, (p24-3) which is part of the major region responsible for protein dimerization. The linear peptide, rp24-3, and its cyclic variant, rp24-3m, were produced by recombinant strategy in Escherichia coli. The gene fragments were obtained by the synthetic gene approach and inserted into pET $32 \mathrm{a}$ to produce fusion proteins in the soluble form. The expression products were purified by Niaffinity chromatography followed by an enzymatic cleavage. The peptides where purified by reverse phase chromatography and their primary sequence and molecular masses where inferred by amino acid sequence analysis and mass spectrometry, respectively. The rp24-3 secondary structure was investigated by circular dichroism and steady state fluorescence, been structured differently in water and in buffer. Besides, its tryptophan is in a partially buried environment and the addition of methanol above $70 \%$ caused a highly increase in helical content. In conclusion, this work shows a suitable system for rp24-3 production, providing satisfactory amount for structural studies. [8]

Thirty-nine $(9.3 \%)$ of 421 blood donors who were found to be positive for HIV-1 by the confirmatory test, Western blot, were considered to be possible false positives because they lacked reactivity to the polymerase protein of HIV, p31 endonuclease. Twenty of the 39 were proven to be uninfected by polymerase chain reaction and therefore Western blot false positives. The false positive prevalence was $4.8 \%$ of positive Western blot donors and $0.0004 \%$ or one in 251 000 donations for all donors. These were the findings of a retrospective cohort study of more than 5 million blood donors who gave blood at five centres from 1991 to 1995. The purpose of the study was to validate an algorithm for selecting possible false positive donors for further testing and to determine the Western blot patterns that are most predictive (1).

Until the early 1990s, a Western blot result was considered positive if three specific HIV-1 gene products were detected: a core (Gag) protein, p24; an envelope (Env) protein, gp41 or gp120/160; and a polymerase (endonuclease) protein, p31. In 1993 the requirement of p31 reactivity for a positive Western blot reaction was dropped to reduce the number of indeterminate results, in high risk screening settings, among those seroconverting or with late stage AIDS. The results of this study, however, suggest that the lack of a p31 band is an important parameter for a potential false positive Western blot result. An additional test, on the original specimen, is a better method for resolving indeterminate Western blot results. This method has been used since March 1996 as part of routine blood screening in the US.
This study emphasises the importance of taking a later specimen and looking for the presence of p31 as an indication of seroconversion to resolve indeterminate Western blot results. [9]

\section{THE CHEMISTRY AND COMPOSITION OF} THREE MOLECULES:

1, 7-Bis (4-hydroxy-3-methoxyphenyl)-1, 6-heptadiene-3, 5Dione

2,. 3beta-Hydroxyurs-12-en-28-oic acid beta-Ursolic acid $=$ Ursolsaeure Ursolic acid, beta

3 Cyperus rotundus

Periodical tests observation:

Comparative \& Randomized Clinical Trial Data:

The bioactive composition of the present invention according to working examples (1,2 and 3 ) disclosed under Example 1 on page no. 13 of the original specification as filed, were selected for the clinical trial in patients with HIV/AIDS. The patients were divided into 4 groups as following:

Group A: 10 patients were provided Curcumin 95\% as $200 \mathrm{mg}$ capsules.

Group B: 5 patients were provided Ursolic acid $2 \%$ as 200 mg capsules.

Group C: 5 patients were provided Cyperone as $200 \mathrm{mg}$ capsules.

Group D: 27 patients were provided bioactive composition of the present invention as $500 \mathrm{mg}$ capsules.

Dosing schedule of the medications in each of the above groups were carried out as follows:

1. Curcumin was administered in dosing schedule of 800 $\mathrm{mg}$ to $1200 \mathrm{mg}$ daily depending on the severity of the infection for a period of 6 months.

2. Ursolic acid was administered in dosing schedule of $1200 \mathrm{mg}$ to $3000 \mathrm{mg}$ daily depending on the severity of the infection for a period of 6 months.

3. Cyperone was administered in dosing schedule of 1200 $\mathrm{mg}$ to $3000 \mathrm{mg}$ daily depending on the severity of the infection for a period of 6 months

4. Bioactive composition was administered in dosing schedule of 2000 to $3000 \mathrm{mg}$ daily depending on the severity of the infection for a period of 6 months.

These groups (group A, B and C) had regular anti-HIV medications like Bleomycin, azithromycin, amitryptyline, ritonavir, acyclovir before initiating therapy with Curcumin, Ursolic acid and Cyperone respectively and these medications were stopped at the time of commencement of the study. In the bioactive composition group (Group D), all regular conventional medications were stopped and only multivitamins, antacids were continued. Weight management, Blood Pressure, Sugar levels, Mental activity, Cardiac history, HB, TCDC, Skin eruption, Dietary composition, renal 
and digestive tracks activity, Liver function activity, addiction history, sexual behavior, surgical track records, thyroid functions, mensustral position were observed with the reputed pathology laboratory. HIV-1 and HIV-2 tests were performed by one of the following laboratory tests: ELISA, Western blot, PCR and CD4 count.

In addition, presence of key glycoproteins like p17, p41, p24, p31, p51, p55, p66 was noted by Western blot technique before and at the end of the study. These glycoproteins were also tested periodically, for evaluating the clinical response by observing the elimination of these glycoproteins. The results of the study are disclosed below:Tables 1, 2, 3 and 4

\section{Observations:}

From the above findings, it is clear that none of the patients in group $\mathrm{A}, \mathrm{B}$ or $\mathrm{C}$ who was administered one of the ingredients of the bioactive composition showed removal of key glycoproteins at the end of the treatment when tested by the laboratory methods for presence/absence of glycoproteins.

However, in the last group (group D) wherein the patients were provided bioactive composition, all the patients showed removal of one or more of glycoproteins, which as confirmed by laboratory tests. This has been shown in Table 2Table 4 patient-wise data wherein the glycoprotein(s) removed have been identified. These patients also showed increase in CD4 count at the end of the treatment in many patients when tested for CD4 count. This has direct relation as removal of glycoprotein(s) is itself accounted for increase in CD4 count. Also in this group 4, there were patients who were on conventional medication for just one month; these patients voluntarily shifted to bioactive composition therapy on account of increase in symptoms of HIV during one month of treatment with conventional medications.

\section{CONCLUSION:}

Based on the above findings, it is clear that the bioactive composition of the present invention showed synergistic effect compared to individual ingredients.

Special: I tender my special vote of thanks to the US Department of Health, US FDA, European Drug Discovery Council, Belgium, World Health Organization, Geneva for their outstanding guidance. I am also indebted to my wife Harsh and two daughters, Sejal and Kunjal for their significant deication of time. The discovery project was financed by my family.

\section{REFERENCES:}

1. THE NEW MICROBIOLOGICA, 29, 1-10, 2006 Functions of the HIV-1 matrix protein p17 Simona Fiorentini, Elena Marini, Sonia Caracciolo, Arnaldo Caruso-Department of Experimental and Applied Medicine, Section of Microbiology, University of Brescia, Italy
2. HIV-1 matrix protein p17 enhances the proliferative activity of natural killer cells and increases their ability to secrete proinflammatory cytokines: Authors: Vitale M.; Caruso A.1; De Francesco M.A.1; Rodella L.2; Bozzo L.1; Garrafa E.1; Grassi M.1; Gobbi G.3; Cacchioli A.4; Fiorentini S. Source: British Journal of Haematology, Volume 120, Number 2, January 2003, pp. 337-343(7) Publisher: Blackwell Publishing.

3. Stephen Matthews ${ }^{*} \%$, Paul Barlow ${ }^{*}$, Jonathan Boyd\%, Geoff Barton+, Robert Russell+, Helen Mills\#, Mark Cunningham\#, Nicola Meyers\#, Nigel Burns\#, Nigel Clark*, Susan Kingsman*, Alan Kingsman* and Iain Campbell* \%. Department of Biochemistry, University of Oxford, Oxford OX1 3QU, UK. + Laboratory of Molecular Biophysics, University of Oxford, Oxford OX1 3QU, UK. \# British Biotechnology Ltd, Watlington Road, Oxford OX4 5LY \% Oxford Centre for Molecular Sciences, University of Oxford, Oxford OX1 3QU, UK.

4. Human antibody to matrix protein (p17) neutralizes HIV in vitro. Kageyama S, Ismail S, Katsumoto T, Hossain M, Gao M, Taniguchi K, Sasao F, Toya M, Wakamiya N, Tsuchie H. Int Conf AIDS. 1994 Aug 7-12; 10: 86 (abstract no. PA0224). Dept. Pathol. Res. Inst. for Microbial Dis., Osaka Univ., Suita, Japan. 5. The affinity of IgG antibodies to gag p24 and p17 in HIV-1-infected patients correlates with disease progression. D Chargelegue, C M Stanley, C M O'Toole, B T Colvin, and M W Steward London Hospital Medical College, UK.

6. HIV-1 matrix protein p17 increases the production of proinflammatory cytokines and counteracts IL- 4 activity by binding to a cellular receptor- de Francesco, Maria A.; Baronio, Manuela; Fiorentini, Simona; Signorini, Costantino; Bonfanti, Carlo; Poiesi, Claudio; Popovic, Mikulas; Grassi, Manuela; Garrafa, Emirena; Bozzo, Luisa; Lewis, George K.; Licenziati, Stefano; Gallo, Robert C.; Caruso, Arnaldo Proceedings of the National Academy of Science, vol. 99, Issue 15, p.9972-9977-07/2002: ImmunologyPNAS2002PNAS...99.9972D

7. HIV p17 reverses the anti-inflammatory activity of IL-4 on IL-15 stimulated monocytes and modulates their ability to secrete MIP-1 alpha M.A. De Francesco, C. Poiesi, D. Ricotta and N. Manca Institute of Microbiology and Virology, University of Brescia, Brescia, Italy Institute of Biochemistry, University of Brescia, Brescia, Italy

8. Mallam Nock Joshua1, Qi Yipeng1, Huang Yongxiul and Liu Ziye1 Supported by the World Bank Boan Program Priscila Vasques Castilho Belongs to: BDTD Ibict

9. Kleinman S, Busch MP, Hall L, Thomson R, Glynn S, Gallahan D et al. Falsepositive HIV-1 test results in a low risk screening setting of voluntary blood donation. JAMA 1998; 280: 1080-85. (http://www.ama-assn.org/public/ journals/jama/) Eurosurveillance, Volume 2, Issue 40, 01 October 1998 Articles 
Table 1. HIV PATIENTS TREATED WITH CURCUMIN 95\% AS MONOTHERAPY (GROUP A)

\begin{tabular}{|c|c|c|c|c|c|}
\hline No. & $\begin{array}{l}\text { Patient } \\
\text { Code }\end{array}$ & $\begin{array}{l}\text { Co-medication (conventional) before } \\
\text { treatment with Curcumin }\end{array}$ & $\begin{array}{l}\text { Duration of } \\
\text { conventional } \\
\text { drugs }\end{array}$ & $\begin{array}{l}\text { Removal of glycoproteins (p17, p41, } \\
\text { p24, p31, p51, p55, p66) }\end{array}$ & $\begin{array}{l}\text { Major side } \\
\text { effects, if any }\end{array}$ \\
\hline 1 & DP-1 & Bleomycin & 6 months & None & None \\
\hline 3 & MK-5 & Matronidazole, Nalidixic acid & 6 months & None & Acidity \\
\hline 4 & JG-7 & Acyclovir, Clofazimine & 6 months & None & Weakness \\
\hline 5 & GD-8 & Amitriptyline, Clotrimazole & 6 months & None & None \\
\hline 6 & KS-9 & Foscarnet, Ritonavir & 6 months & None & None \\
\hline 7 & GB-10 & Cyproheptadine, Acyclovir & 6 months & None & $\begin{array}{l}\text { Mild gut } \\
\text { disturbance }\end{array}$ \\
\hline 8 & JP-13 & $\begin{array}{l}\text { Foscarnet, Clofazimine, } \\
\text { Ketoconazole }\end{array}$ & 6 months & None & Severe fatigue \\
\hline 9 & PB-15 & Filgastrim, Omeprazole, Foscarnet & 6 months & None & Fatigue \\
\hline 10 & KV-19 & $\begin{array}{l}\text { Filgastrim, Ciprofloxacin, } \\
\text { Omeprazole }\end{array}$ & 6 months & None & Weakness \\
\hline
\end{tabular}

Table 2. HIV PATIENTS TREATED WITH URSOLIC ACID 2\% AS MONOTHERAPY (GROUP B)

\begin{tabular}{|c|c|c|c|c|c|}
\hline No. & $\begin{array}{l}\text { Patient } \\
\text { Code }\end{array}$ & $\begin{array}{l}\text { Co-medication (conventional) before } \\
\text { treatment with ursolic acid }\end{array}$ & $\begin{array}{l}\text { Duration of } \\
\text { conventional } \\
\text { drugs }\end{array}$ & $\begin{array}{l}\text { Removal of glycoproteins (p17, } \\
\mathrm{p} 41, \mathrm{p} 24, \mathrm{p} 31, \mathrm{p} 51, \mathrm{p} 55, \mathrm{p} 66)\end{array}$ & $\begin{array}{l}\text { Major side } \\
\text { effects, if any }\end{array}$ \\
\hline 1 & PP-21 & Acyclovir, Zalcitabine & 6 months & None & None \\
\hline 3 & AC-29 & Ciprofloxacin, Lamivudine & 6 months & None & $\begin{array}{l}\text { Profound } \\
\text { weakness }\end{array}$ \\
\hline 4 & RK-33 & Beclomethasone, Ritonavir & 6 months & None & Restlessness \\
\hline 5 & DK-37 & Astemizole, Filgastrim, Zalcitabine & 6 months & None & None \\
\hline
\end{tabular}

Table 3. HIV PATIENTS TREATED WITH CYPERONE ASMONOTHERAPY (GROUP C)

\begin{tabular}{lllll}
\hline No. & $\begin{array}{l}\text { Patient } \\
\text { Code }\end{array}$ & $\begin{array}{l}\text { Co-medication (conventional) before } \\
\text { treatment with cyperone }\end{array}$ & $\begin{array}{l}\text { Duration of } \\
\text { conventional } \\
\text { drugs }\end{array}$ & $\begin{array}{l}\text { Removal of glycoproteins (p17, p41, } \\
\text { p24, p31, p51, p55, p66) }\end{array}$ \\
1 & CP-43 & Ciprofloxacin, Somastostatin & 6 months & None \\
2 & NK-48 & Ethambutol, Lamivudine & 6 months & None \\
3 & VS-51 & Not known & 6 months & None \\
4 & N-56 & Beclomethasone, Ritonavir & 6 months & None \\
5 & GR-61 & Sparfloxacin, Prednisolone & 6 months & None \\
\hline
\end{tabular}


Table 4. HIVPATIENTS TREATED WITH BIOACTIVE COMPOSITION COMPRISING OF CURCUMIN-95\%, URSOLICACID 2\% AND CYPERONE IN ORAL DOSAGE FORM (GROUP D)

\begin{tabular}{|c|c|c|c|c|c|}
\hline No. & $\begin{array}{l}\text { Patient } \\
\text { Code }\end{array}$ & $\begin{array}{l}\text { Co-medication (conventional) before } \\
\text { treatment with bioactive composition }\end{array}$ & $\begin{array}{l}\text { Duration of } \\
\text { conventional } \\
\text { drugs }\end{array}$ & $\begin{array}{l}\text { Removal of glycoproteins (p17, } \\
\text { p41, p24, p31, p51, p55, p66) }\end{array}$ & $\begin{array}{l}\text { Side effects, } \\
\text { if any }\end{array}$ \\
\hline 1 & JP-2 & Acetaminophen & 12 months & $\mathrm{p} 17, \mathrm{p} 41$ & $\begin{array}{l}\text { Gut } \\
\text { disturbance }\end{array}$ \\
\hline 2 & LK-4 & Cyproheptadine, Foscarnet, Zalcitabine & 18 months & p24 & None \\
\hline 3 & GH-6 & Quantor, Calpol & 9 months & p31 & None \\
\hline 4 & JH-7 & Acyclovir, Clofazimine, Zalcitabine & 5 months & $\mathrm{p} 41, \mathrm{p} 51 / 55$ & None \\
\hline 5 & KS-9 & Clofazimine, Foscarnet, Ritonavir & 6 months & p17, p31 & None \\
\hline 6 & NP-11 & Clofazimine, Filgastrim, Foscarnet & 24 months & $\mathrm{p} 17, \mathrm{p} 31, \mathrm{p} 51 / 55$ & None \\
\hline 7 & JP-13 & Zalcitabine, Foscarnet, Ketoconazole & 7 months & p17 & None \\
\hline 8 & GB-16 & Azithromycin, Foscarnet & 24 months & p17, p51/55 & None \\
\hline 9 & PP-21 & Acyclovir, Zalcitabine & 6 months & p17, p55; CD 4 count increased & None \\
\hline 10 & JP-25 & Dronabinol, Saquinavir, Clofazimine & 7 months & $\mathrm{p} 41, \mathrm{p} 66$ & $\begin{array}{l}\text { Mild } \\
\text { nausea }\end{array}$ \\
\hline 11 & AP-29 & Lamivudine, Ciprofloxacin & 6 months & p17, p31 & Headache \\
\hline 12 & VP-31 & Acyclovir, Azithromycin, Megesterol & 5 months & $\mathrm{p} 17, \mathrm{p} 51 / 55$ & None \\
\hline 13 & RK-33 & Ritonavir, Beclomethasone, Clofazimine & 6 months & p17 & None \\
\hline 14 & $\mathrm{KV}-44$ & Combiflam & 3 months & $\mathrm{p} 17, \mathrm{p} 41, \mathrm{p} 51 / 55$ & None \\
\hline 15 & NK-48 & Lamivudine, Norfloxacin, Ethambutol & 18 months & p17, p31 & None \\
\hline 16 & VS-51 & Ritomune, Zedavir & 6 months & $\mathrm{p} 17, \mathrm{p} 41$ & None \\
\hline 17 & NP-52 & Virodin, AZT, Prednisolone & 6 months & $\mathrm{p} 17, \mathrm{p} 31, \mathrm{p} 51 / 55$ & Nausea \\
\hline 18 & LM-54 & Forcan, Acyclovir & 6 months & p17 & None \\
\hline 19 & GR-61 & Rifabatin, Zalcitabine, Astemizole & 6 months & p31, p66 & $\begin{array}{l}\text { Mild gut } \\
\text { disturbance }\end{array}$ \\
\hline 20 & GT-62 & AZT, Astemizole & 1 month & p17; CD4 count increased & None \\
\hline 21 & GT-63 & Zalcitabine, Foscarnet & 1 month & p17; CD4 count increased & $\begin{array}{l}\text { Mild } \\
\text { nausea }\end{array}$ \\
\hline 22 & PS-64 & Cyproheptadine, Azithromycin, & 2 years & p51, p24; CD4 count increased & None \\
\hline 23 & NJ-65 & Conventional HIV drugs & 2 years & $\mathrm{p} 17, \mathrm{p} 41$ & None \\
\hline 24 & AP-68 & Ritonavir, Clofazimine, Doxycycline & 2 years & p17; CD4 count increased & None \\
\hline 25 & KM-73 & Virolis, Didanosine, Foscarnet, Saquinavir & 2 months & p31 & $\begin{array}{l}\text { Mild } \\
\text { nausea }\end{array}$ \\
\hline 26 & MZ-74 & Forcan, Quantor, Ketoconazole & 1 month & $\mathrm{p} 17, \mathrm{p} 41$ & None \\
\hline 27 & HK-76 & $\begin{array}{l}\text { Conventional drugs taken; details not } \\
\text { known }\end{array}$ & 2 years & $\mathrm{p} 41$ & None \\
\hline
\end{tabular}

